\title{
The Importance of Social Skills for Autism
}

\author{
Lutfi Isni Badiah \\ Special Education Department \\ University of PGRI Adi Buana Surabaya \\ Surabaya, Indonesia \\ lutfiisnibadiah@gmail.com
}

\begin{abstract}
Social skills are one of the important aspects in human life. The lack of social skills can affect a person's future life. Autism Spectrum Disorder (ASD) or known as autism is a development characterized by difficulties in social communication and showing repetitive behavior. This causes children with autism to have difficulty mastering social skills. Therefore, children with autism need social skills interventions that can help them to participate in the community. The article will discuss the importance of social skills and procedures that are useful for teaching social skills to autistic children so that they can be accepted in community life.
\end{abstract}

Keywords—-social skills; autisme spectrum disorder.

\section{INTRODUCTION}

Children with Autism Spectrum Disosder (ASD) have experience developmental disorders by showing symptoms such as learning disabilities, language and communication problems, lack of attention, and hyperactivity [1]. According to Hill and Frith, children with autism spectrum disosder have experienced difficulties in planning, problems with initiating new things, and are often trapped in the assignments given [2]. Meanwhile, according to IDEA, children with autism spectrum disosder are mental disabilities that cause difficulties in communication both verbal and non-verbal, and in interacting socially which occurs before the age of three years. Children with autism spectrum disosder usually show several symptoms including repetitive activities, stereotypical behavior, resistance to environmental changes or changes in daily routines and unusual responses to sensory experiences [3]

The characteristics of children with autism spectrum disosder as described previously lead to a lack of social skills and social interaction. Difficulties in social skills and social interaction are characteristic of children with autism spectrum disosder although this level of difficulty depends on the age level and the level of high or absence of autism. Social skills are the ability of people to behave according to a particular situation. According to Takahashi in reference [4], social skills are defined as social acceptance, learning behaviors that allow a person to interact effectively with others and to avoid unacceptable social responses. A person who has high social skills can be easily accepted by others in society.

Well-developed social skills can help children with disabilities to develop strong and positive friend relationships, succeed in school, and begin successfully exploring the role of adults such as employees, coworkers/co-workers, and community members. Social skills also support the positive development of healthy adult relationships with family members and peers. Hair et al. in reference [5] stated that a teenager who has strong social skills is more likely to be accepted by peers, develop friendships, maintain strong relationships with parents and peers, are able to solve problems effectively, foster greater interest in school and do better in academic skill.

Social skills are an important aspect for children including children with special needs, especially for children with autism spectrum disosder. Children with autism spectrum disosder also need interaction with people around their environment. This is reinforced by the opinion of reference [6], which states that it is important for each child to have a positive relationship with peers in the middle and late childhood. For example, engaging in positive interactions with peers, resolving conflicts, and having a sense of friendship.

Young children with autism spectrum disosder often show delays in social skills such as limited eye contact. Whereas adolescents with autism often show difficulty in maintaining interaction with others, difficulty understanding and using nonverbal communication (gestures and facial expressions), as well as difficulties in giving back to conversations [7].

Without assistance, they find it difficult to start conversations, play with friends, join activities, and follow games and understand the rules. According to reference [8], lack of social relationships in childhood can lead to a decline in employment, a decrease in independent life according to life expectancy and severe mental health problems (such as depression, suicidal desires, and anxiety). In addition, autistic children are also vulnerable to be bullied by their peers.

This is supported by reference [4], that poor skills can cause underprivileged children to establish relationships with other people. Children who have poor skills tend to have unpleasant relationships with others and get negative feedback. Improving skills in children with autism spectrum disosder is important because it can have an impact on low performance at school and at work.

\section{METHOD}

The method used in this paper was the description analysis of literature study. A literature study was done by finding the relevant theory to the issues discussed. Primary and secondary 
data were drawn from the various sources used as the main data in this paper.

\section{RESULT AND DISCUSSION}

\section{A. Social Skills For Children With Autism Spectrum Disosder}

The social skills that normal children have to get are generally expressed by reference [4], which are adapted from Gresham and Elliott (1990) as follows.

TABLE I. CHILDREN SOCIAL SKILLS

\begin{tabular}{|c|c|c|}
\hline No & Aspect & Indicator \\
\hline 1. & Cooperation & $\begin{array}{l}\text { Listen to the other people talking. } \\
\text { Get permission before using } \\
\text { someone else's property } \\
\text { Avoid behavior that causes } \\
\text { problems. } \\
\text { Do the assigments on time. } \\
\text { Maintain cleanliness and neatness. } \\
\text { Set free time. } \\
\text { Follow directions and instructions. } \\
\text { Use the right tone of voice. } \\
\text { Ignore interference. } \\
\text { Help with housework }\end{array}$ \\
\hline 2. & Assertion & $\begin{array}{l}\text { Make friends easily. } \\
\text { Ask for help when you need it. } \\
\text { Confident in interaction. } \\
\text { Participate in several activities. } \\
\text { Give praise. } \\
\text { Receive praise. } \\
\text { Start a conversation. } \\
\text { Invite other people to participate in } \\
\text { an activity. } \\
\text { Volunteer in helping. } \\
\text { Express feelings correctly. }\end{array}$ \\
\hline 3. & Responsibility & $\begin{array}{l}\text { Say good things. } \\
\text { Show concern for friends. } \\
\text { Express feelings correctly. } \\
\text { Follow directions and rules. } \\
\text { Waiting for your turn in an } \\
\text { activity. } \\
\text { Request permission when going. } \\
\text { Report something right. } \\
\text { Preferred by others / social } \\
\text { acceptance. } \\
\text { Answer the phone well }\end{array}$ \\
\hline 4. & Empathy & $\begin{array}{l}\text { Understand the feelings of others. } \\
\text { Request help for the problem. } \\
\text { Say sorry for the bad things that } \\
\text { happen to others. } \\
\text { Listen to friends who tell stories } \\
\text { about their problem. } \\
\text { Smile. } \\
\text { Notify when someone is doing } \\
\text { good. } \\
\text { Defend friends who don't get fair } \\
\text { treatment. } \\
\text { Talk about a problem or opinion } \\
\text { with classmates. }\end{array}$ \\
\hline 5. & Self-control & $\begin{array}{l}\text { Ignore temptations or distractions. } \\
\text { Express disagreement with } \\
\text { without anger. } \\
\text { Avoid things that cause problems. } \\
\text { Do something good. } \\
\text { Compromise with other people's } \\
\text { opinions. } \\
\text { Receive punishment from adults. } \\
\text { Control emotions. }\end{array}$ \\
\hline
\end{tabular}

\begin{tabular}{|l|l|l|}
\hline No & \multicolumn{1}{|c|}{ Aspect } & \multicolumn{1}{c|}{ Indicator } \\
\hline & & $\begin{array}{l}\text { Receive criticism without anger. } \\
\text { Respond precisely to the behavior } \\
\text { of others. } \\
\text { Reject something politely. } \\
\text { Speak in the right tone. }\end{array}$ \\
\hline
\end{tabular}

Social skills for children with special needs are certainly different from normal children, according to the type of needs and characteristics. According to reference [9], the social skills of children with special needs with cognitive difficulties, social or behavioral problems, and general delays in social and cognitive functions tend to show low social skills. According to reference [10], there are some social skills that must be mastered by children with autism spectrum disosder in the transition age as follows.

TABLE II. THE SOCIAL SKILLS OF CHILDREN WITH AUTISM DiSORDER

\begin{tabular}{|c|c|c|c|c|c|}
\hline \multirow[b]{2}{*}{ Social Skills } & \multicolumn{5}{|c|}{ Skills } \\
\hline & $\begin{array}{c}\text { Peer } \\
\text { Relati } \\
\text { ons }\end{array}$ & $\begin{array}{c}\text { Self } \\
\text { Manageme } \\
\text { nt }\end{array}$ & $\begin{array}{l}\text { Acade } \\
\text { mic }\end{array}$ & $\begin{array}{c}\text { Obedie } \\
\text { nce }\end{array}$ & $\begin{array}{c}\text { Aserti } \\
\text { on }\end{array}$ \\
\hline Be On time & & $\sqrt{ }$ & & $\sqrt{ }$ & \\
\hline $\begin{array}{l}\text { Use loudness and } \\
\text { the right tone of } \\
\text { voice }\end{array}$ & & $\sqrt{ }$ & & & \\
\hline $\begin{array}{l}\text { Encourage } \\
\text { everyone } \\
\text { participate }\end{array}$ & $\sqrt{ }$ & & & & \\
\hline $\begin{array}{l}\text { Study } \\
\text { names }\end{array}$ & $\sqrt{ }$ & & & & \\
\hline See people talking & $\sqrt{ }$ & & & & \\
\hline $\begin{array}{l}\text { Make eye contact } \\
\text { with others when } \\
\text { talking }\end{array}$ & $\sqrt{ }$ & & & & \\
\hline $\begin{array}{l}\text { Check someone's } \\
\text { understanding and } \\
\text { ask appropriate } \\
\text { questions }\end{array}$ & & & $\sqrt{ }$ & & $\sqrt{ }$ \\
\hline $\begin{array}{l}\text { Describes } \\
\text { someone's feelings } \\
\text { when needed }\end{array}$ & $\sqrt{ }$ & $\sqrt{ }$ & & & $\sqrt{ }$ \\
\hline $\begin{array}{l}\text { Build other } \\
\text { people's comments } \\
\text { and ideas }\end{array}$ & $\sqrt{ }$ & & $\sqrt{ }$ & & \\
\hline $\begin{array}{l}\text { Support others } \\
\text { both verbally and } \\
\text { nonverbally }\end{array}$ & $\sqrt{ }$ & & & & \\
\hline $\begin{array}{l}\text { Request direction } \\
\text { or help }\end{array}$ & & $\sqrt{ }$ & $\sqrt{ }$ & & \\
\hline $\begin{array}{l}\text { Participate } \\
\text { appropriately in } \\
\text { small talk }\end{array}$ & $\sqrt{ }$ & & & & \\
\hline $\begin{array}{l}\text { Start and respond } \\
\text { to humor }\end{array}$ & $\sqrt{ }$ & & & & \\
\hline
\end{tabular}




\section{B. Social Skills Intervention Strategy For Children With Autism Spectrum Disosder}

TABLE III. INTERVENTION STRATEGY TO TRAIN SOCIAL SKILLS FOR CHILDREN WITH AUTISM SPECTRUM DISOSDER

\begin{tabular}{|l|l|l|l|l|l|}
\hline \multirow{2}{*}{ Social Skills } & \multicolumn{4}{|c|}{ Skills } \\
\cline { 2 - 6 } & $\begin{array}{c}\text { Peer } \\
\text { Rela- } \\
\text { tions }\end{array}$ & $\begin{array}{c}\text { Self } \\
\text { Manage- } \\
\text { ment }\end{array}$ & Academic & $\begin{array}{c}\text { Obe- } \\
\text { dience }\end{array}$ & Asertion \\
\hline $\begin{array}{l}\text { Support } \\
\text { others both } \\
\text { verbally and } \\
\text { nonverbally }\end{array}$ & $\sqrt{ }$ & & & & \\
\hline $\begin{array}{l}\text { Request } \\
\text { direction or } \\
\text { help }\end{array}$ & & $\sqrt{ }$ & & \\
\hline $\begin{array}{l}\text { Participate } \\
\text { appropriatel } \\
\text { in small } \\
\text { talk }\end{array}$ & $\sqrt{ }$ & & & & \\
\hline $\begin{array}{l}\text { Start and } \\
\text { respond to } \\
\text { humor }\end{array}$ & $\sqrt{ }$ & & & & \\
\hline
\end{tabular}

One of the efforts to help children with autism spectrum disosder is by establishing cooperation between all parties, namely parents, friends, teachers and schools. It is important to give positive feelings to the interaction of children with autism spectrum disosder. Schools must provide socialization to children through interaction by providing support for a conducive environment. In this case, the teacher plays an important role to support the interaction between children with autism spectrum disosder and peers.

There have been many interventions designed to overcome the lack of social skills of children with autism spectrum disosder. This intervention varies according to the child's age and the severity of the autism. In choosing and implementing programs to teach social skills for children with autism spectrum disosder, according to reference [5], it needs to pay attention to the following steps.

- Establish a steering committee

- Conduct a needs assessment and careful preparation during coordination

- Choose the right program

- Develop plans for implementation in the first year

- Review, plan for expansion, and focus on development

- Monitor the implementation process and evaluate the impact of the program.

In teaching social skills for children with autism spectrum disosder, it is necessary to remove barriers to interaction and help children understand social action functions. Following are the types of social skills interventions recommended according to reference [7].
TABLE IV. INTERVENTION STRATEGY TO TRAIN SOCIAL SKILLS FOR CHILDREN WITH AUTISM SPECTRUM DISORDER

\begin{tabular}{|l|l|l|}
\hline No. & \multicolumn{1}{|c|}{ Intervention } & \multicolumn{1}{c|}{ Explanation } \\
\hline & Peer Assistance & $\begin{array}{l}\text { Peers are trained to interact with } \\
\text { children with autism spectrum } \\
\text { disosder by encouraging the } \\
\text { development of positive social skills } \\
\text { in regular classroom settings }\end{array}$ \\
\hline Social Skills Group & $\begin{array}{l}4-5 \text { children with autism spectrum } \\
\text { disosder are included in lessons about } \\
\text { some social skills in schools and } \\
\text { clinics. In groups, it can also include } \\
\text { peers as models / mentors }\end{array}$ \\
\hline Video modeling & $\begin{array}{l}\text { children with autism spectrum } \\
\text { disosder watch videos that show } \\
\text { themselves or peers demonstrating } \\
\text { certain social skills, and then practice } \\
\text { them. }\end{array}$ \\
\hline Social Stories & $\begin{array}{l}\text { children with autism spectrum } \\
\text { disosder read short stories written in } \\
\text { the settings of the first person to use } \\
\text { the right social skills }\end{array}$ \\
\hline & $\begin{array}{l}\text { children with autism spectrum } \\
\text { disosder see a sequence of images } \\
\text { about social skills to learn how and } \\
\text { why to do those skills. }\end{array}$ \\
\hline &
\end{tabular}

\section{1) Peer Assistance}

Normal peer assistance is a type of traditional social skills intervention that is shared with normal children in regular classes. In this model, normal peers are taught how to interact with children with autism spectrum disosder to encourage the development of social skills. Peers are taught for example how to be good friends, how to play with children with autism spectrum disosder, and talk with children with autism spectrum disosder even if he does not respond. This model is appropriate to use in the setting of inclusive education.

Furthermore, just participating in inclusive class settings is not enough to increase the social interaction and social skills of children with autism spectrum disosder. Because without intervention, normal peers prefer other normal friends than autistic children. But with training, usually normal children are able and willing to interact with children with autism spectrum disosder. Using this model in inclusive settings has proven to be one of the most effective strategies for improving social communication skills of children with autism spectrum disosder.

\section{2) Social Skills Group}

This model is the most commonly used intervention for school-aged children with autism spectrum disosder. In this group, it consists of 4-5 children with autism who participate in social skills lessons taught by the teacher or therapist. This group usually meets at school or in outpatient clinics with children with autism spectrum disosder from the other community. This session topic includes greeting others, being friendly, joining or starting playing with others, reading nonverbal cues, and starting and maintaining conversations with others. Here are some topics taught in social skills groups. 
TABLE V. Discussion TOPICS IN SOCIAL SKILLS GROUP

\begin{tabular}{|l|l|}
\hline \multicolumn{1}{|c|}{ Children Group } & \multicolumn{1}{c|}{ Teenager group } \\
\hline Know someone & Meeting new people / ask something \\
\hline Body language (nonverbal) & Using body language \\
\hline Controling emotion & $\begin{array}{l}\text { Using body signals to express and } \\
\text { understand the emotion }\end{array}$ \\
\hline Conversation & Positive thinking \\
\hline Tease vs jokes & Teenager's problem \\
\hline Tips for making friends & Sharing the opinion \\
\hline
\end{tabular}

Another factor that can help in the success of social skills groups is the inclusion of normal peers who have been trained to encourage the social skills of children with autism spectrum disosder. In this model, involving normal peers with strong social skills and interest in helping children with autism spectrum disosder voluntarily to serve as peer mentors and receive training before participating.

Before involving normal peers in this social skills group, they need to be given training and tips to deal with children with autism spectrum disosder, as stated by reference [5] as follows.

- As much as possible for concrete in children with autism spectrum disosder, including explaining sarcasm, dual meanings in jokes, and idioms

- Normal peers are expected to be direct, because facial expressions and body language cues are not effective in communicating with children with autism spectrum disosder.

- Peers are asked to avoid using long sentences, and use short and clear sentences because children with autism spectrum disosder often have difficulty finding the subject

- Peers need to know that some children with autism spectrum disosder are sensitive to sounds, smells, sights, or other feelings that can make them unable to concentrate on other things.

- Peers are expected not to be easily offended by the behavior of children with autism spectrum disosder who sometimes say inappropriate things that might hurt their feelings. However, children with autism spectrum disosder need to be guided to understand the feelings of others.

\section{3) Video Modeling}

This model is a type of intervention in which children with children with autism spectrum disosder disosder see a demonstration of videos about themselves or others who successfully perform appropriate social skills, then imitate the skills modeled in the video. According to research, this type of intervention is effective for children and adolescents with autism to learn many types of skills, including social skills. This model is most effective when combined with other interventions to teach social skills.

\section{4) Social Stories and Picture Books}

Social stories are short and individual stories written to teach skills or social behavior, or about concepts, or events. This procedure for making social stories involves parents or teachers in writing short stories about children with autism spectrum disosder.The stories are about skills, activities, or events, and aims to let children know what, when, where, why, events that will occur, and the expected response from children with autism spectrum disosder. For example, parents and teachers can write social stories about certain social skills such as greeting others, participating in activities, or giving praise. Social stories about greeting others can depict children shaking hands with other children, asking questions, and explaining why children need to do this and the results.

According to research, this intervention through social stories proved effective when used as part of a more comprehensive social skills program. The use of picture books is also similar to social stories in teaching social skills. It is just accompanied by photos or children's comics that show various social skills and explain why they use these skills.

\section{CONCLUSION}

Lack of social skills is characteristic of children with autism spectrum disorders (ASD). This lack of social skills certainly gives negative impact on autistic children to hang out in the school and community environment. Without assistance, children with autism spectrum disosder find it difficult to start conversations, play with friends, join activities, and follow games and understand the rules. Lack of social relationships in childhood can lead to a decline in employment, a decrease in independent life and life expectancy, and severe mental health problems (such as depression, suicidal desires, and anxiety). In addition, children with autism spectrum disosder are also vulnerable to be bullied by their peers.

Teachers need to pay attention to the social development of each student, including students with special needs, including children with autism spectrum disosder. It is expected that teachers can help students with special needs to be able to have and develop good social skills with friends and the community. There are various social skills intervention strategies that can be used to help children with autism spectrum disosder, including involving normal peer assistance, forming social skills groups, using video modeling, social cheerfulness and picture books to make it easier for children with autism spectrum disosder to do social skills. Students with special needs need to interact and socialize with others. Creating an environment that supports the development of social skills of students with special needs can also have a positive impact on students.

\section{REFERENCES}

[1] J. F. Mwakalinga, teaching social interaction for learner with autism (a study of how teachers aim to influence development of social interaction for learners with autism). Trykk: Reprosentralen, Universitetet i Oslo, 2012.

[2] E. L. Hill, and U. Frith, "Understanding Autism: insight form mind and brain," Philosophical transaction: Biological sciences, vol. 358, no. 1430, pp. 281-289, Feb. 2003. 
[3] W. L. Heward, Execeptional Children: an introduction to special education. USA: Pearson Education Inc., 2009.

[4] R. Diahwati, R. Hariyono, and F. Hanurawan, "Keterampilan sosial siswa berkebutuhan khusus di sekolah dasar inklusi," Jurnal Pendidikan: Teori, Penelitian dan Pengembangan, vol. 1, no. 8, pp. 1612-1620, Aug. 2016.

[5] C. D. Bremer, and J. Smith. "Teaching Social Skills," Addresing Trends and Developments in Secondary education and transition, vol. 3, no. 5, pp. 1-5, Oct. 2004.

[6] J. W. Santrock, Psikologi Pendidikan. Jakarta: Kencana, 2004.
[7] A. J. Bohlander, F. Orlich, and C. K. Varley. "social skills training for children with autism," Departement of Psychiatry, vol. 59, no. 1, pp. 165-174, Feb. 2012.

[8] P. S. Strain, and I. Schwartz. "ABA and the develpment of meaningfu social realtions for young children with autism," Focus on Autism and Other Developmental Disabilities, vol. 16, no. 2, pp. 120-128, May. 2015.

[9] J. E. Omrod, Psikologi Pendidikan Jilid 1. Jakarta: Erlangga, 2009.

[10] F. M. Gresham, G. Sugai, and R. H. Horner. "Intepreting outcomes of social skills training for student with high-incidence disabilities," Exceptional Children, vol. 67, no. 3, pp. 331-344, Jul. 2001 